\title{
MENINGKATKAN KEMAMPUAN PEMECAHAN MASALAH MELALUI PENDEKATAN KONTEKSTUAL PADA SISWA KELAS VIII DI KABUPATEN BANDUNG BARAT
}

\author{
Yani Komalasari ${ }^{1}$, Resti Naila Nayara Tasya ${ }^{2}$, Neni Maryani ${ }^{3}$, Fitriani Nursalamah ${ }^{4}$, Nani Marlina ${ }^{5}$, \\ Wahyu Hidayat ${ }^{6}$ \\ 1,2,3,4,5,6 IKIP SILIWANGI, Jl. Terusan Jendral Sudirman, Cimahi tengah, Kota Cimahi, Jawa Barat \\ yanikomalasari65@gmail.com
}

\begin{abstract}
The purpose of this study is to examine the achievement of problem solving abilities of junior high school students using contextual and teaching leaning learning. The study population included all seventh grade students of SMP in West Bandung Regency. From the population that was taken randomly, namely class VII I amounted to 44 students using a leaning contextual and teaching approach and class VII $\mathrm{J}$ amounted to 44 students with classes using conventional learning. The data collection used is a test question in the form of a test of problem solving ability totaling five questions with indicators (1) understanding the problem (2) planning completion (3) completion according to plan (4) checking again. To test the effectiveness of learning by using a leaning contextual and teaching approach and conventional tests used inality tests. To compare the average achievement of contextual learning and leaning teaching and conventional learning the data were analyzed using the two sample t-test. The results of this study indicate that the overall achievement of problem-solving skills is seen that there are differences using contextual learning and leaning teaching rather than conventional learning.
\end{abstract}

Keywords: Problem Solving Ability, contextual and teaching leaning, Conventional

\begin{abstract}
Abstrak
Tujuan dari penelitian ini adalah untuk menelaah pencapaian kemampuan pemecahan masalah siswa SMP menggunakan pembelajaran contextual and teaching leaning. Populasi penelitian mencakup seluruh siswa kelas VII SMP di Kabupaten Bandung Barat. Dari populasi yang adadiambil secara acak yaitu kelas VII I berjumlah 44 siswa dengan menggunakan pendekatan contextual and teaching leaning dan kelas VII J berjumlah 44 siswa menggunakan pembelajaran konvensional. Pengumpulan data yang dipakai adalah soal tes berupa tes kemampuan pemecahan masalah yang berjumlah lima soal dengan indicator (1) memahami masalah (2) merencanakan penyelesaian (3) penyelesaian sesuai rencana (4) memeriksa kembali. Untuk menguji kefektifan pembelajaran dengan menggunakan pendekatan contextual and teaching leaning dan konvensional digunakan uji normality test. Untuk membandingkan rata-rata pencapaian pembelajaran contextual and teaching leaning dan pembelajaran konvensional data dianalisis menggunakan uji two sample t-test. Hasil penelitian ini menunjukkan bahwa dilihat secara keseluruhan pencapaian kemampuan pemecahan masalah terdapat perbedaan yang menggunakan pembelajaran contextual and teaching leaning daripada pembelajaran konvensional.
\end{abstract}

Kata Kunci : Kemampuan Pemecahan masalah, contextual and teaching leaning, Konvensional

Matematika merupakan ilmu dasar yang harus dikembangkan dan dipelajari oleh setiap siswa. Dengan demikian, matematika wajib diajarkan kepada siswa disetiap jenjang pendidikan dimulai dari Sekolah dasar sampai dengan perguruan tinggi. Sekolah merupakan lembaga pendidikan dan tempat berlangsungnya berbagai kegiatan, terutama kegiatan belajar mengajar yang tidak hanya melibatkan guru dan siswa, melainkan beberapa komponen lain yaitu kurikulum, sarana dan prasarana, 
lingkungan dan komponen lain yang saling mempengaruhi. Jika salah satu komponen tersebut tidak berjalan dengan semestinya, maka proses belajar mengajar akan terganggu dan hasil belajar yang diinginkan tidak akan tercapai. Oleh karena itu, untuk mendapatkan hasil belajar, maka setiap komponen harus saling mendukung.

Adapun tujuan dalam pembelajaran matematika adalah suatu proses interaksi timbal balik guru dan siswa dalam mencapai tujuan pendidikan. Tujuan pembelajaran matematika tertera pada peraturan pemerintah Nomor 22 tahun 2006 yang menjelaskan bahwa mata pelajaran matematika memiliki tujuan agar siswa memiliki kemampuan sebagai berikut: 1) Memahami konsep matematika, menjelaskan keterkaitan pemahaman konsep dan mengaplikasikan konsep atau algoritma, secara luwes, akurat, efisien, dan tepat dalam pemecahan masalah; 2) Menggunakan penalaran pada pola dansifat. Melakukan manipulasi matematika dalam membuat generalisasi, menyusun bukti atau menjelaskan suatu ide dan pernyataan matematika; 3) Memecahkan masalah, yang mencakup kemampuan memahami masalah, merancang model matematika, menyelesaikan model dan menjelaskan solusi yang diperoleh; 4) Mengkomunikasikan gagasan dengan symbol, tabel, diagram, atau media lainuntuk memperjelas keadaan atau masalah; 5) Memiliki sikap menghargai kegunaan matematika dalam keseharian, yaitu memiliki rasa ingin tahu, perhatian, dan minat dalam mempelajari matematika, serta ulet danpercaya diri dalam pemecahan masalah. Menurut Akbar, Hamid, Bernard, Sugandi (2018) pemecahan masalah matematika merupakan hal yang sangat penting dalam pembelajaran matematika karena dapat mempermudah siswa dalam menghadapi masalah-masalah dalam kehidupan siswa pada hari ini dan pada hari yang akan datang. Fauzan (2002) berpendapat bahwa siswa di Indonesia kurang memiliki dalam sikap kritis dalam menyelesaikan suatu masalah matematika. Mereka hanya menerapkan aturan dalam penyelesaian yang telah diajarkan tanpa memahami konsep di dalamnya. Penyebab masalah tersebut adalah karena siswa lebih senang menyelesaikan masalah dengan cara singkat atau cara praktis dengan penjelasan yang biasanya diajarkan lembaga bimbingan belajar di luar sekolah tanpa memperhatikan konteks masalah yang diberikan dan tanpa mengkaji konsep matematis yang berlaku dalam masalah tersebut. Menurut Fitraini \& Fitri (2018) Tidak berkembangnya kemampuan pemecahan masalah bukan sepenuhnya kesalahan dari siswa, tetapi kesalahan juga terdapat dari guru yang cenderung menerapkan pembelajaran konvensional.

Kemampuan pemecahan masalah memang harus ditumbuh kembangkan pada siswa mengingat begitu pentingnya posisi kemampuan pemecahan masalah dalam matematika. Polya (dalam Fatmawati, 2014)) mengungkapkan tahapan-tahapan pemecahan masalah yaitu memahami masalah atau persoalan (understand the problem), menyusun rencana pemecahan masalah (make a plan), melaksanakan rencana pemecahan (carry out a plan), dan memeriksa kembali (look back at the completed solution). Zulfah (2017) mengemukakan gejala-gejala yang berkaitan dengan rendahnya kemampuan pemecahan masalah matematis diantaranya sebagian besar siswa tidak bisa: 1) Mengerjakan soal yang berbeda dari contoh soal yang diberikan guru 2) Memahami soal yang 
Meningkatkan Kemampuan Pemecahan Masalah Melalui Pendekatan Kontekstual Pada Siswa Kelas VIII di Kabupaten Bandung Barat, Yani Komalasari, Resti Naila Nayara Tasya, Neni Maryani, Fitriani Nursalamah, Nani Marlina, Wahyu Hidayat

berbentuk soal cerita dengan baik 3) Menyelesaikan soal-soal aplikasi atau soal-soal pemecahan masalah, dan 4) Menjawab soal dengan langkah-langkah umum pemecahan masalah. Sejumlah penelitian menunjukkan efektifitas dari pembelajaran kontekstual dalam mengembangkan kemampuan siswa. Berdasarkan penelitian yang telah dilakukan oleh (Sumartini, 2016) yang menyatakan bahwa kemampuan pemecahan masalah siswa dalam pembelajaran matematika masih tergolong rendah. Masing-masing tahapan saling berkaitan satu sama lain sehingga siswa dapat menyelesaikan soal kemampuan pemecahan masalah. Dalam pembelajaran siswa belum dapat memecahakan suatu permasalahan dan belum bisa menyelesaikan melalui tahap-tahap. Karena dengan kemampuan pemecahan masalah belum maksimal dalam pembelajaran peneliti peneliti menggambil pendekatan kontekstual. Menurut Sanjaya (2006) yang menyatakan bahwa dalam proses pembelajaran kontekstual, dunia belajar setiap siswa pasti berbeda dan seorang guru perlu memahami itu, artinya penyesuaian dalam gaya mengajar pada tipe belajar siswa sangat perlu diatasi. Menurut Nurhadi dalam Rusman (2013) pembelajaran kontekstual adalah konsep belajar yang membantu guru mengaitkan antara materi yang diajarkannya dengan situasi dunia nyata siswa serta mendorong siswa membuat hubungan antara pengetahuan yang dimilikinya dengan keterampilan dalam kehidupan sehari-harinya.

Menurut Trianto (2007) bahwa pada pembelajaran kontekstual guru dibantu dengan konsep belajar yang menghubungkan keterkaitan antara materi ajar dengan situasi dunia nyata dan mendorong siswa mengkaitkan dengan pengetahuan yang dimilikinya lalu menerapkan dalam kehidupan. Hal tersebut sejalan dengan Ruqoyyah (2017) Pendekatan kontekstual merupakan konsep belajar yang menghadirkan situasi nyata pada keseharian manusia dan dibawa ke dalam kelas juga memotivasi siswa untuk membuat relasi antara pengetahuan yang siswa miliki dengan penerapannya dalam kehidupan sehari-hari. Menurut beberapa ahli diatas dapat diartikan bahwa dalam pembelajaran matematika menggunakan pendekatan kontekstual guru harus membiasakan diri untuk tidak menjadi sumber informasi melainkan sebagai fasilitator, sehingga siswa sangat dituntut untuk berpartisipasi dalam proses pembelajaran dengan mengaitkan materi ke dalam dunia nyata dan menemukan arti di dalam proses pembelajarannya. Keaktifan siswa dalam pembelajaran menggunakan pendekatan kontekstual dapat dilihat dari gaya belajar yaitu visual, auditorial dan kinestetik.

Menurut Kadir (2013) Karakteristik pembelajaran kontekstual yaitu : 1) Kerja sama; 2) saling menunjang; 3) menyenangkan dan tidak membosankan; 4) Belajar dengan bergairah; 5) pembelajaran terintegrasi; 6) menggunakan berbagai sumber; 7) siswa aktif; 8) sharing dengan teman; 9) siswa kritis, guru kreatif; 10) mengapresiasi hasil kerja siswa dengan memampangkan pada ruangan atau lorong; 11) laporan kepada orang tua bukan hanya rapor tetapi hasil karya siswa, laporan hasil pratikum, karangan siswa, dan lain-lain

Menurut Sanjaya (2006) kontekstual sebagai suatu pendekatan pembelajaran memiliki 7 asas yaitu :

\section{Kontruktivisme (constructivism)}


Kontruktivisme adalah proses membangun suatu pengetahuan baru dalam siswa berdasarkan pengalaman. Menurut Sanjaya (2006) pengetahuan itu memang berasal dari luar, akan tetapi dikontruksi dari diri seseorang. Oleh sebab itu, pengetahuan terbentuk oleh dua faktor penting, yaitu objek yang menjadi bahan pengamatan dan kemampuan subjek untuk menginterpretasi objek tersebut.

\section{Inkuiri (Inquiry)}

Inkuiri artinya proses pembelajaran berdasarkan pada pencarian dan menemukannya melalui proses berpikir secara runtut. Pengetahuan bukanlah hanya sejumlah fakta atau kebenaran mengingat, akan tetapi hasil dari proses menemukan sendiri.

\section{Bertanya (Questioning)}

Peran bertanya sangatlah penting, sebab melalui pertanyaan-pertanyaan guru dapat membimbing dan mengarahkan siswa untuk menemukan setiap materi yang dipelajari. Pembelajaran menggunakan pendekatan kontekstual, guru menyampaikan informasi begitu saja tetapi memancing agar siswa dapat menemukan sendiri.

4. Masyarakat belajar (Learning Community)

Learning community merupakan salah satu metode dari kerjasama. Hasil belajar diperoleh melalui shering antar teman, antar kelompok dan antara yang tahu ke yang belum tahu. Aktivitas ini terjadi bila tidak ada pihak yang dominan dalam komunikasi, tidak ada pihak yang merasa sungkan untuk bertanya dan tidak ada pihak yang menganggap dirinya yang paling mengerti. Setiap pihak harus mempunyai pemikiran bahwa setiap orang lain memiliki pengetahuan serta keahlian yang berbeda yang perlu dipelajari.

\section{Pemodelan (Modeling)}

Pemodelan adalah pembelajaran dilakukan dengan menampilkan model yang bisa dilihat, dirasa dan bahkan bisa ditiru oleh siswa. Dalam praktiknya guru bukan merupakan satu-satunya model. Karena model yang disampaikan akan menjadi standar kompetensi yang akan dicapai, maka jika guru belum mampu menjadi model maka dapat mendatangkan model dari luar. Model tersebut bisa diambil beberapa siswa yang dianggap mampu, atau para pakar ke dalam kelas.

\section{Refleksi (Reflection)}

Refleksi adalah suatu kegiatan yang telah dilaksanakan atau dipelajari dari proses pembelajaran. Melalui refleksi, pengalaman belajar itu akan dimasukan dalam struktur kognitif siswa yang pada akhirnya akan menjadi bagian dari pengetahuan yang dimiliki siswa.

7. Penilaian sebenarnya (Authentic Assesment)

Penilaian nyata adalah proses yang dilakukan guru untuk menganalisa tentang perkembangan belajar yang dilakukan siswa.

Segala sesuatu yang ada, baik itu teori ataupun konsep tidak akan terlepas dari nilai positif dan negatif, ada kekurangan dan ada juga kelabihan itulah dalam dunia pendidikan selalu ada inovasi baru dalam rangka memecahkan masalah agar sesuai dengan zamanya dan mencapai target yang 
Meningkatkan Kemampuan Pemecahan Masalah Melalui Pendekatan Kontekstual Pada Siswa Kelas VIII di Kabupaten Bandung Barat, Yani Komalasari, Resti Naila Nayara Tasya, Neni Maryani, Fitriani Nursalamah, Nani Marlina, Wahyu Hidayat

sudah direncanakan. Pada pendekatan konstektual ini tidak semuanya positif, ada beberapa hal yang menjadi kelemahan dan kelebihan. Sebagaimana menurut pendapat Sanjaya (2006) kelebihan dan kekuranganya adalah: 1) CTL adalah pendekatanpembelajaran yang menekankan pada aktivitas siswa secara penuh, baik fisikmaupun mental, 2) CTL memandang bahwa belajar bukan menghafal, akan tetapiproses berpengalaman dalam kehidupan nyata, 3) Kelas dalam pembelajaran CTLbukan sebagai tempat untuk memperoleh informasi, akan tetapi sebagai tempatmenguji data hasil temuan siswa di lapangan, dan 4) Materi pelajaran ditemukanoleh siswa sendiri, bukan hasil pemberian dari orang lain. Kemendikbud (2013) menyebutkan bahwa pembelajaran dengan pendekatan kontekstual yaiutu suatu konsep pembelajaran dimana guru menghadirkan siswa membuat hubungan antara pengetahuan yang dimilikinya dengan penerapannya. Hal ini disebabkan karena pendekatan pembelajaran kontekstual berorientasi pada penyelesainya masalah kehidupan sehari-hari yang dapat memicu proses berfikir kritis, logis, dan kreatif sehingga siswa memiliki kemampuan sebagai sosok problem solver. Akan tetapi penelitian-penelitian tersebut dilakukan dalam konteks pembelajaran lain. Sedangkan, kemampuan pemecahan masalah dengan menggunakan pendekatan kontekstual pada mata pelajaran matematika masih minim dilakukan olehpara peneliti.

Oleh karena itu, penelitain ini bertujuan untuk menemukan model pembelajaran kontekstual yang dapat membangun kemampuan siswa dalam pemecahan masalah pada mata pelajaran matematika. Berdasarkan argument tersebut, peneliti mengambil judul "Meningkatkan Kemampuan Pemecahan Masalah Pada Materi Persamaan Garis Melalui Pendekatan Kontekstual Pada Siswa Kelas VIII di Kabupaten Bandung Barat”.

\section{METODE}

Metode penelitian ini menggunakan metode kuantiitatif yang bertujuan untuk menelaah pencapaian kemampuan pemecahan masalah siswa SMP menggunakan pembelajaran contextual and teaching leaning. Data yang dikumpulkan berupa test instrument kemampuan pemecahan masalah berjumlah 5 butir soal yang mencakup indikator kemampuan pemecahan masalah yaitu (1) memahami masalah (2) merencanakan penyelesaian (3) penyelesaian sesuai rencana (4) memeriksa kembali. Populasi penelitian ini berupa siswa kelas VII SMP Di Kabupaten Bandung Barat dengan memilih sampel secara acak, kelas yang dijadikan sampel yaitu kelas VII I dengan total 44 siswa yang menerapkan pembelajaran konvensional dan kelas VII J berjumlah 44 siswa menggunakan pendekatan contextual and teaching leaning. Kemudian Data tersebut diberikan skor sesuai dengan pedoman penskoran Sumarmo (2016) yang ada pada Tabel 1 lalu data di uji normality test. Untuk melihat rata-rata pencapaian pembelajaran dengan contextual and teaching leaning dan pembelajaran konvensional data dianalisis dengan menggunakan uji two sample t-test. 


\section{Tabel 1}

Rubrik Pemberian Skor Pemecahan Masalah Matematik

\begin{tabular}{|c|c|c|}
\hline $\begin{array}{l}\text { Aspek yang } \\
\text { dinilai }\end{array}$ & Skor & Keterangan \\
\hline \multirow{3}{*}{$\begin{array}{l}\text { Pemahaman } \\
\text { Masalah }\end{array}$} & 0 & Salah menginterpretasikan soal/tidak ada jawaban sama sekali \\
\hline & 1 & Salah menginterpretasikan sebagian soal atau mengabaikan isi soal \\
\hline & 2 & Memahami masalah/soal selengkapnya \\
\hline \multirow{4}{*}{$\begin{array}{l}\text { Perencanaan } \\
\text { Penyelesaian }\end{array}$} & 0 & $\begin{array}{l}\text { Menggunakan strategi yang tidak relevan/tidak ada strategi sama } \\
\text { sekali }\end{array}$ \\
\hline & 1 & $\begin{array}{l}\text { Menggunakan satu strategi yang kurang tepat dilaksanakan dan tidak } \\
\text { dapat dilanjutkan }\end{array}$ \\
\hline & 2 & $\begin{array}{l}\text { Menggunakan sebagian strategi yang benar tapi mengarah pada } \\
\text { jawaban yang salah atau tidak mencoba strategi yang lain }\end{array}$ \\
\hline & 3 & Menggunakan beberapa prosedur yang mengarah ke solusi yang benar \\
\hline \multirow{4}{*}{$\begin{array}{l}\text { Penyelesaian } \\
\text { Masalah Sesuai } \\
\text { Rencana }\end{array}$} & 0 & Tidak ada solusi sama sekali \\
\hline & 1 & Menggunakan beberapa prosedur yang mengarah ke solusi yang benar \\
\hline & 2 & $\begin{array}{l}\text { Hasil salah satu atau sebagian hasil salah tetapi hanya salah sau } \\
\text { perhitungannya saja }\end{array}$ \\
\hline & 3 & Hasil dan solusi benar \\
\hline \multirow{3}{*}{$\begin{array}{l}\text { Pemerikasaan } \\
\text { Kembali Hasil } \\
\text { Perhitunagan }\end{array}$} & 0 & Tidak ada pemeriksaan tetapi atau tidak ada keterangan apapun \\
\hline & 1 & Ada pemerikasaan tapi tidak tuntas \\
\hline & 2 & Pemeriksaan dilaksanakan untuk melihat keterangan hasil dan proses \\
\hline
\end{tabular}

\section{HASIL DAN PEMBAHASAN}

Setelah melaksanakan pembelajaran dengan menggunakan pendekatan contextual and teaching leaning pada kelas eksperimen dan kelas kontrol selanjutnya dilakukan pengolahan data hasil penelitian. Data tersebut diperoleh dari test kemampuan pemecahan masalah, pengolahan data dilakukan dengan bantuan software spss 16 untuk menguji hipotesis penelitian. 
Meningkatkan Kemampuan Pemecahan Masalah Melalui Pendekatan Kontekstual Pada Siswa Kelas VIII di Kabupaten Bandung Barat, Yani Komalasari, Resti Naila Nayara Tasya, Neni Maryani, Fitriani Nursalamah, Nani Marlina, Wahyu Hidayat

Tabel 2

Deskripsi Statistik Hasil Skor Kemampuan Pemecahan Masalah

\begin{tabular}{|c|c|c|c|c|c|}
\hline \multirow{2}{*}{ Variabel } & \multirow{2}{*}{ Kelas } & \multicolumn{4}{|c|}{ Statistic } \\
\cline { 3 - 6 } & & $\mathbf{N}$ & $\begin{array}{c}\text { Rata- } \\
\text { Rata }\end{array}$ & $\boldsymbol{x}_{\text {max }}$ & $\boldsymbol{x}_{\text {min }}$ \\
\hline $\begin{array}{c}\text { Kemampuan Pemecahan } \\
\text { Masalah }\end{array}$ & Eksperimen & 44 & 63.00 & 90 & 0 \\
\cline { 2 - 6 } & Kontrol & 44 & 25.36 & 68 & 0 \\
\hline
\end{tabular}

Berdasarkan Tabel 2 diatas maka dapat dikemukakan hasil kemampuan pemecahan masalah kelas eksperimen skor rata-rata postes adalah 63.00 dan kelas kontrol skor rata-rata adalah 25.36. Kemudian dilanjutkan uji statistik untuk mengetahhui apakah ada perbedaan yang signifikan antara kemampuan pemecahan masalah siswa kelas eksperimen dan kelas kontrol tetapi sebelum itu akan dilakukan uji normalitas terlebih dahulu dengan hasil dibawah ini:

\section{Tabel 3}

Hasil Uji Normalitas Data Postes Kemampuan Pemecahan Masalah

\begin{tabular}{|ll|r|r|r|}
\hline \multirow{2}{*}{} & kelas & \multicolumn{3}{|c|}{ Kolmogorov-Smirnov $^{\mathrm{a}}$} \\
\cline { 2 - 5 } & Statistic & \multicolumn{1}{c|}{ df } & \multicolumn{1}{c|}{ Sig. } \\
\hline postes & 1 & .142 & 44 & .026 \\
& 2 & .148 & 44 & .017 \\
\hline
\end{tabular}

Berdasarkan tabel diatas dengan hipotesis :

$\mathrm{H}_{\mathrm{o}}$ : sampel berdistribusi normal

$\mathrm{H}_{\mathrm{a}}$ : sampel tidak berdistribusi normal

Dengan kriteria :

jika signifikansi $\geq 0,05$ maka Ho diterima

jika signifikansi $<0,05$ maka Ho ditolak

Maka terlihat bahwa nilai signifikansi kedua kelas $<0,05$ maka $\mathrm{H}_{\mathrm{o}}$ ditolak artinya sampel tidak berdistribusi normal karena kedua tidak berdistribusi normal maka kedua kelas dilakukan uji non parametrik mann whitney. 
Berdasarkan hasil perhitungan sebelumnya diperoleh kesimpulan bahwa kedua kelas tidak berdistribusi normal sehingga pengujian hipotesis dilakukan dengan uji statistik non parametrik mann whitney. Hipotesis dalam pengujian ini dirumuskan sebagai berikut:

$\mathrm{H}_{0}$ : pencapaian kemampuan pemecahan masalah melalui pendekatan contextual and teaching leaning tidak lebih baik dari pada yang menggunakan pembelajaran konvensional

$\mathrm{H}_{\mathrm{a}}$ : pencapaian kemampuan pemecahan masalah melalui pendekatan contextual and teaching leaning lebih baik dari pada yang menggunakan pembelajaran konvensional

\section{Tabel 4}

Hasil Uji Signifikansi Perbedaan Rata-Rata Postes Kemampuan Pemecahan Masalah

\begin{tabular}{|c|c|c|}
\hline & & postes \\
\hline Mann-Whitney U & & 208.000 \\
\hline Wilcoxon W & & $1.198 \mathrm{E} 3$ \\
\hline $\mathrm{Z}$ & & -6.347 \\
\hline Asymp. Sig. (2-tailed) & & .000 \\
\hline Monte Carlo Sig. (2- & Sig. & $.000^{\mathrm{a}}$ \\
\hline tailed) & 95\% Confidence Interval Lower Bound & .000 \\
\hline & Upper Bound & .000 \\
\hline Monte Carlo Sig. (1- & 95\% Confidence Interval Lower Bound & .000 \\
\hline tailed) & Upper Bound & .000 \\
\hline & Sig. & $.000^{\mathrm{a}}$ \\
\hline
\end{tabular}

Berdasarkan data pada Tabel 4 diperoleh nilai signifikansi Monte Carlo sig. (1-tailed) 0,000 atau $<0,05$ maka $\mathrm{H}_{0}$ ditolak artinya pencapaian kemampuan pemecahan masalah melalui pendekatan contextual and teaching leaning lebih baik dari pada yang menggunakan pembelajaran konvensional.

Dari hasil analisis data postes diperoleh denganrata-rata nilai kelas eksperimen yaitu 63.00 dan rata-rata nilai kelas kontrol 25.36 serta hal tersebut juga diperkuat dengan uji perbedaan dua rata-rata yang dilakukan dengan uji t' satu pihak yang mengahasilkan nilai signifikansi 0,000 berarti nilai signifikansi $<0,05$ sehingga dapat disimpulkan bahwa pencapaian kemampuan pemecahan masalah yang menggunakan penedekatan contextual and teaching leaning lebih baik dibandingkan dengan kelas yang diberikan pembelajaran konvensional. Hal ini sejalan dengan penelitian yang dilakukan oleh Setiawan \& Harta (2014) pembelajaran matematika dengan pendekatan kontekstual efektif di tinjau dari kemampuan pemecahan masalah dan sikap siswa terhadap matematika Berdasarkan data diatas dapat diketahui bahwa pencapaian kemampuan pemecahan masalah siswa yang pembelajarannya yang menggunakan pendekatan contextual and teaching leaning lebih baik daripada pembelajaran konvensional. Hal itu dikarenakan pendekatan contextual and teaching leaning menuntut siswa untuk berperan lebih aktif dalam proses pembelajaran dan lebih percaya diri untuk 
Meningkatkan Kemampuan Pemecahan Masalah Melalui Pendekatan Kontekstual Pada Siswa Kelas VIII di Kabupaten Bandung Barat, Yani Komalasari, Resti Naila Nayara Tasya, Neni Maryani, Fitriani Nursalamah, Nani Marlina, Wahyu Hidayat

mengungkapkan pendapatnya dalam menyelesaikan soal. Hal itu sependapat dengan Febrianti (2013) Hasil penelitian menunjukkan bahwa penerapan pendekatan kontekstual dalam pembelajaran matematika cukup efektif untuk meningkatkan kemampuan pemecaham masalah matematika siswa, bila dibandingkan dengan pembelajaran langsung.

\section{KESIMPULAN}

Berdasarkan uraian diatas yang dilakukan uji normality test dan uji two sample t-test didapat bahwa rata-rata nilai yang menggunakan pendekatan contextual and teaching leaning lebih tinggi yaitu 63.00 sedangkan kelas control sebanyak 25.36 dan juga terdapat signifikansi antara hasil belajar siswa yang menggunakan pendekatan contextual and teaching leaning dengan hasil belajar siswa yang mneggunakan pendekatan konvensional. Pembelajaran menggunakan pendekatan contextual and teaching leaning menurut Bernard (2015) memiliki tujuh komponen yang dapat mempengaruhi yaitu kontruktivisme, bertanya, menemukan, masyarakat belajar, pemodelan, refleksi dan penilaian sebenarnya. Jadi dapat disimpulkan bahwa pencapaian kemampuan pemecahan masalah terdapat perbedaan yang menggunakan pembelajara contextual and teaching leaning daripada pembelajaran konvensional.

\section{DAFTAR PUSTAKA}

Akbar, P., Hamid, A., Bernard, M., \& Sugandi, A. I. (2018). Analisis kemampuan pemecahan masalah dan disposisi matematik siswa kelas xi sma putra juang dalam materi peluang. Jurnal Cendekia: Jurnal Pendidikan Matematika, 2(1), 144-153.

Bernard, M. (2015). Meningkatkan kemampuan komunikasi dan penalaran serta disposisi matematik siswa SMK dengan pendekatan kontekstual melalui game adobe flash cs 4.0. Infinity Journal, 4(2), 197-222.

Fatmawati, H. (2014). Analisis Berfikir Kritis dalam Pemecahan Masalah Matematik Berdasarkan Polya pada Pokok Bahasan Persamaan Kuadrat. Jurnal Elektronik Pembelajaran Matematika, 2(9), 911-922.

Fauzan, A. (2002). Applying Realistic Mathematics Education in Teaching Geometry in Indonesian

Primary Schools. Doctoral Dissertation, University of Twente, Enschede, The Netherlands.

Febrianti, H. (2013). Efektivitas Penerapan Pendekatan Kontekstual dalam Meningkatkan Kemampuan Pemecahan Masalah Matematika Siswa Kelas VIII SMPN 9 Padang. Prosiding SEMIRATA 2013, 1(1).

Fitriani, D., \& Fitri, I. (2018). Penerapan Pembelajaran Kooperatif dengan Pendekatan Struktural

Think Pair Share untuk Meningkatkan Kemampuan Pemecahan Masalah Mahasiswa. Jurnal Cendekia: Jurnal Pendidikan Matematika, 2(1), 88-96. 
Kadir, A. (2013). Konsep pembelajaran kontekstual di sekolah. Dinamika Ilmu: Jurnal Pendidikan, 13(1).

Ruqoyyah, S (2017). Meningkatkan Kemampuan Komunikasi dan pemecahan masalah serta disposisi matematik siswa MA melalui Contextual Teaching and Learning (TESIS). Program Studi Pendidikan Matematika, STKIP Siliwangi, Bandung.

Rusman. (2013). Model-Model Pembelajaran: Mengembangkan Profesionalisme Guru Edisi Kedua. Jakarta: PT.Rajagrafindo Persada.

Sanjaya, W. (2006). Strategi Pembelajaran Berorientasi Standar Proses Pendidikan. Jakarta: Kencana Prenada Meida Group.

Setiawan, R. H., \& Harta, I. (2014). Pengaruh pendekatan open-ended dan pendekatan kontekstual terhadap kemampuan pemecahan masalah dan sikap siswa terhadap matematika. Jurnal Riset Pendidikan Matematika, 1(2), 241-257.

Sumarmo, U. (2016). Pedoman Pemberian Skor pada Beragam Tes Kemampuan Matematik. Kelengkapan Bahan Ajar Mata Kuliah Evaluasi Pembelajaran Matematika pada Program Magister Pendidikan Matematika STKIP Siliwangi: Tidak diterbitkan.

Sumartini, T. S. (2016). Peningkatan Kemampuan Pemecahan Masalah Matematis Siswa melalui Pembelajaran Berbasis Masalah. Pendidikan Matematika Stkip Garut, 5(mei), 148158.

Trianto. (2007). Model-Model Pembelajaran Inovatif Berorientasi Konstruktivistik. Jakarta.Prestasi Pustaka.

Zulfah, Z. (2017). Pengaruh Penerapan Model Pembelajaran Kooperatif Tipe Think Pair Share Dengan Pendekatan Heuristik Terhadap Kemampuan Pemecahan Masalah Matematis Siswa Mts Negeri Naumbai Kecamatan Kampar. Jurnal Cendekia: Jurnal Pendidikan Matematika, 1(2), 1-12. 